\author{
О.П. Максименко ${ }^{1}$, В.М. Самохвал ${ }^{1}$, А.Ю. Оробцев ${ }^{2}$, О.В. Нікулін ${ }^{1}$, К.К. Марченко ${ }^{1}$ \\ 1 Дніпровський державний технічний університет \\ 2 ПАТ «Дніпровський металургійний комбінат»
}

\title{
МОДЕЛЮВАННЯ ПРОЦЕСУ ПРОКАТУВАННЯ В КЛІТЯХ ДРОТОВОГО БЛОКУ
}

\begin{abstract}
3 використанням розробленої математичної моделі процесу прокатування в дротовому блоці з визначенням середньої результуючої поздовжніх сил в металі, що пластично деформується, досліджено вплив умов тертя на показник сталості процесу прокатування та на міжклітьові натяжіння. На прикладі моделювання процесу прокатування катанки діаметром 5,5 мм доведено, що з збільшенням коефіцієнту тертя поздовжня сталість процесу прокатування по всій лінії дротового блоку збільшується з одночасним зменшенням питомого натяжіння розкату в міжклітьових проміжках. Також виявлено, що за відносно незначних змін обтиснення в першій кліті блоку спостерігаються суттєві зміни режиму натяжінь між клітями та неоднозначні зміни показника сталості процесу прокатування.
\end{abstract}

DOI: $10.34185 / 0543-5749.2020-3-59-68$

\section{Вступ}

До складу сучасних дротових станів входять чистові або калібруючі блоки, які являють собою компактні агрегати, що складаються 3 послідовно розташованих в єдиному корпусі однотипних клітей. Кількість клітей (модулів) в блоках може становити від 4 до 10. Більшість таких блоків мають груповий привод, що обумовлює жорсткий кінематичний зв'язок між клітями. Такі конструктивні особливості блоків дозволяють виготовляти катанку 3 заданими показниками точності та фізико-механічних властивостей. Відповідність показників якості катанки вимогам споживачів сприяє широкому розповсюдженню цього виду прокату в сталедротовому виробництві, машинобудуванні, будівництві та інших галузях. Але, одночасно 3 перевагами застосування дротових блоків, проявляються і їх певні недоліки, одним 3 яких $€$ неможливість контролю або регулювання натяжіння між клітями, що відповідним чином впливає на кінематику і стабільність процесу та обумовлює відхилення розмірів готового прокату.

\section{Аналіз публікацій}

Відома значна кількість публікацій, як у вітчизняних [1-3] так і зарубіжних [4, 5] виданнях, де розглядаються питання теоретичних та експериментальних дослідження i розробок, пов'язаних з технологією прокатування в дротових блоках, їх конструкцією та забезпеченням показників якості готової продукції. В працях $[6,7]$ виконано аналіз впливу розмірів підкату та зносу валків на поздовжню сталість процесу неперервного прокатування та можливості його саморегуляції при виникненні відхилень технологічних параметрів. Згідно досліджень [8] поздовжня сталість процесу визначає межі можливих змін параметрів, таких як нейтральний кут та випередження, за яких сили, що втягують метал в осередок деформування $\epsilon$ достатніми для підтримання стабільності процесу прокатування. В працях [9 - 11] запропонована методика оцінки поздовжньої сталості процесу прокатування за величиною середньої результуючої горизонтальних сил в металі по осередку деформації, яку визначають з залежності:

(C) Максименко О.П., Самохвал В.М., Оробцев А.Ю., Нікулін О.В., Марченко К.К., 2020 


$$
Q_{c p . n p .}^{*}=\frac{1}{\alpha} \int_{0}^{\alpha} Q_{x . n p .}^{*} d \varphi
$$

де $Q_{x . n p .}^{*}=Q_{x . n p .} /\left(2 K_{c p .} \cdot R \cdot b_{c p}\right)$ і $Q_{x . n p .}=\sigma_{x} \cdot h_{x} \cdot b_{c p}-$ поточна поздовжня сила в металі, що пластично деформується, в безрозмірному та розмірному представленні; $\sigma_{x}-$ поздовжне нормальне напруження в металі; $\alpha$ - кут контактування металу з валками; $h_{x}$ - поточна товщина розкату по осередку деформації; $b_{c p}$ - середня ширина розкату по осередку деформації; $R$ - радіус валків; $2 K_{c p}$. середній опір металу деформуванню.

Згідно методики, коли $Q_{c p . n p . ~}^{*}$ менше нуля, тобто напрям дії середньої результуючої сили є протилежним напрямку переміщення металу по осередку, процес прокатування відбувається стабільно, без пробуксовок чи зупинок. У випадках, коли $Q_{c p . n p .}^{*}=0$, процес прокатування можливий, але це граничні нестабільні умови. Якщо величина $Q_{c p . n p .}^{*}>0$ процес прокатування неможливий.

Запропонований критерій поздовжньої сталості процесу прокатування може бути використаний для аналізу параметрів, зокрема для визначення меж саморегулювання за рахунок перерозподілу сил тертя в осередку деформації та викликаних цим змін параметрів прокатування.

\section{Постановка задачі}

Метою даної роботи є дослідження впливу умов тертя в осередку деформування і режиму обтиснень на поздовжню сталість процесу, та на характер зміни міжклітьового натяжіння розкату при прокатуванні в дротовому блоці середньосортового стану 400/200.

\section{Виклад основного матеріалу досліджень}

При розробці математичної моделі прокатування в дротовому блоці з визначенням показника поздовжньої сталості процесу прокатування виходили 3 методу відповідного розкату з врахуванням виконання умови постійності секундного об'єму металу по всім клітям блоку. Випередження металу розраховували за відомою залежністю [12] з врахуванням натяжіння:

$$
S=\frac{R \gamma^{2}}{h_{1}}+\frac{\frac{\sigma_{1}}{2 K_{c p}} \cdot \frac{b_{1}}{b_{c p}}-\frac{\sigma_{0}}{2 K_{c p}} \cdot \frac{b_{0}}{b_{c p}}}{4 \cdot \frac{p_{c p}}{2 K_{c p}} \cdot f}
$$

де $\gamma$ - кут нейтрального перерізу; $h_{1}$ - товщина розкату на виході з осередку деформації; $\sigma_{0}$ и $\sigma_{1}$ - питомі заднє і переднє натяжіння розкату; $p_{c p}-$ середній тиск по осередку деформації; $b_{0}$, $b_{1}$ - ширина розкату до та після проходу.

Розширення металу в осередку деформації визначали за формулою Петрова-Зібеля з врахуванням коефіцієнту $C$, значення якого наведено в роботі [2]. Крім цього, враховували вплив натяжіння розкату на розширення згідно досліджень О.І. Целікова [13].

Використовуючи математичну модель процесу прокатування в дротовому блоці, виконано аналіз впливу коефіцієнту тертя на силу $Q_{c p . n p .}^{*}$, як показник сталості процесу, та натяжіння між клітями блоку для випадку прокатування низьковуглецевої катанки діаметром 5,5 мм 3 підкату діаметром 17,3 мм. За незмінного режиму обтиснень, що відповідав звичайному для цього профілерозміру прокату, коефіцієнт тертя змінювали на чотирьох рівнях: $f=0,26 ; 0,28 ; 0,3$; 0,32. Приклад результатів моделювання для випадку використання моделі тертя $t_{x}=f p_{x}$ при $f=0,26$, наведено в таблиці 1. Отримані 3 рішення рівняння Т. Кармана епюри напружень та сил, на прикладі прокатування в другій кліті блоку, показано на рисунку 1.

Як видно з рисунку, поздовжні напруження $\frac{\sigma_{1}}{2 K_{c p}}$ на значній частині осередку деформації є стискаючими і лише поблизу площини входу в осередок деформації вони стають розтягуючими. Поточні значення поздовжніх внутрішніх сил $Q_{x . n p .}^{*}$ у у відповідності з діючими нормальними напруженнями в металі, спрямовані в основному проти напрямку руху розкату, що дає підстави вважати процес прокатування в даній кліті сталим. Середня результуюча цих сил дорівнює $Q_{c p . n p .}^{*}=-0,0108$.

Для інших клітей блоку отримано аналогічні розподіли поздовжніх нормальних напружень по довжині осередку деформування. 
Отже, згідно отриманим даним, середні результуючі сил пластично деформованого

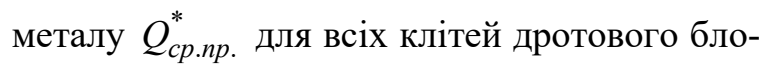
ку мають негативні значення, тобто напрямок їх дії протилежний напрямку переміщення металу в осередках деформування, що свідчить про сталість процесу прокатування. Обчислені значення середніх результуючих сил дозволяють оцінити ступінь сталості процесу прокатування в кожній 3 клітей блоку. Наприклад, якщо для кліті № $2 Q_{c p . n p .}^{*}=-0,0108$, а для кліті № 10
$Q_{c p . n p .}^{*}=-0,0164$, то в останній кліті процес прокатування має більший ступінь сталості.

3 аналізу даних таблиці 1 слідує, що для зазначеного режиму обтиснень питомі натяжіння розкату між клітями порівняно невеликі, що забезпечує підтримання точних розмірів як розкатів так і готової катанки. Значення випередження для перших клітей дещо менші ніж для наступних. Безрозмірний тиск по клітям блоку змінюється у межах $1,09 \div 1,35$ і має тенденцію до зростання по ходу прокатування.

Таблиця 1. Геометричні, кінематичні та силові параметри прокатування катанки Ø 5,5

\begin{tabular}{|c|c|c|c|c|c|c|c|c|c|c|c|c|c|c|}
\hline \multicolumn{15}{|c|}{ Реальні геометричні розміри розкатів та інші параметри } \\
\hline № & $\begin{array}{l}h_{0} \\
\text { мM }\end{array}$ & $\begin{array}{l}h_{1}, \\
\text { мM }\end{array}$ & $\begin{array}{l}\Delta h, \\
\text { MM }\end{array}$ & $\begin{array}{l}b_{0}, \\
\text { мм }\end{array}$ & $\begin{array}{l}b_{1}, \\
\text { мМ }\end{array}$ & $\begin{array}{c}V_{0}, \\
\mathrm{M} / \mathrm{c}\end{array}$ & $\begin{array}{c}V_{6}, \\
\mathrm{M} / \mathrm{c}\end{array}$ & $\begin{array}{l}V_{1}, \\
\mathrm{M} / \mathrm{c}\end{array}$ & $\begin{array}{c}F_{0}, \\
\mathrm{MM}^{2}\end{array}$ & $\begin{array}{c}F_{1} \\
\mathrm{MM}^{2}\end{array}$ & $\begin{array}{l}R_{k}, \\
\text { MM }\end{array}$ & $\begin{array}{l}B_{k}, \\
\text { MM }\end{array}$ & $\begin{array}{l}h_{6 p}, \\
\text { MM }\end{array}$ & $\begin{array}{c}g, \\
\text { MM }\end{array}$ \\
\hline 1 & 17,3 & 11,0 & 6,3 & 17,3 & 21,1 & 10,5 & 12,9 & 13,5 & 234,9 & 181,8 & 102,6 & 23,7 & 4,6 & 1,80 \\
\hline 2 & 21,1 & 13,8 & 7,3 & 11,0 & 13,8 & 13,5 & 16,0 & 16,5 & 181,8 & 149 & 101,7 & 13,83 & 6,14 & 1,50 \\
\hline 3 & 13,8 & 9,1 & 4,7 & 13,8 & 16,6 & 16,5 & 19,9 & 20,8 & 149 & 118,6 & 103,3 & 18,89 & 3,5 & 2,10 \\
\hline 4 & 16,6 & 11,0 & 5,6 & 9,1 & 11,0 & 20,8 & 25,1 & 26,1 & 118,6 & 94,37 & 102,5 & 11,45 & 4,95 & 1,06 \\
\hline 5 & 11,0 & 6,5 & 4,4 & 11,0 & 14,3 & 26,1 & 31,6 & 33,6 & 94,37 & 73,35 & 104 & 16,85 & 2,7 & 1,12 \\
\hline 6 & 14,3 & 8,6 & 5,7 & 6,5 & 8,6 & 33,6 & 40,0 & 42,1 & 73,35 & 58,41 & 103,3 & 8,97 & 3,7 & 1,27 \\
\hline 7 & 8,6 & 5,5 & 3,1 & 8,6 & 10,8 & 42,1 & 49,9 & 53,0 & 58,41 & 46,48 & 104,4 & 13,56 & 2,1 & 1,30 \\
\hline 8 & 10,8 & 6,9 & 3,9 & 5,5 & 6,9 & 53,0 & 63,2 & 66,7 & 46,48 & 36,88 & 103,9 & 7,27 & 2,92 & 1,01 \\
\hline 9 & 6,9 & 4,4 & 2,5 & 6,9 & 8,5 & 66,7 & 79,6 & 84,6 & 36,88 & 29,09 & 104,7 & 10,24 & 1,6 & 1,16 \\
\hline 10 & 8,5 & 5,5 & 3,0 & 4,4 & 5,5 & 84,6 & 98,0 & 103,8 & 29,09 & 23,72 & 104,4 & 5,76 & 2,18 & 1,14 \\
\hline
\end{tabular}

\begin{tabular}{|c|c|c|c|c|c|c|c|c|c|c|c|c|c|}
\hline \multicolumn{14}{|c|}{ Геометричні розміри, приведені до відповідного розкату, та інші параметри } \\
\hline № & $\begin{array}{c}h_{0 \text { прр }} \\
\text { Мм }\end{array}$ & $\begin{array}{c}h_{1 \text { прр }} \\
\text { Мм }\end{array}$ & $\begin{array}{c}\Delta h_{n p} \\
\mathrm{MM}\end{array}$ & $\begin{array}{c}b_{0 \text { пр }} \\
\text { Мм }\end{array}$ & $\begin{array}{c}b_{1 \text { пр }}, \\
\text { Мм }\end{array}$ & $\begin{array}{l}\alpha_{y}, \\
\text { рад }\end{array}$ & $\mathrm{Q}^{*}{ }_{c p . n p}$ & $p_{c p} / 2 k_{c p}$ & $\gamma$ & $R \gamma^{2} / h_{1}$ & $q_{0} / 2 k_{c p}$ & $q_{1} / 2 k_{c p}$ & $\mathrm{~S}$ \\
\hline 1 & 15,33 & 9,75 & 5,58 & 15,33 & 18,65 & 0,233 & $-0,0158$ & 1,15 & 0,065 & 0,0452 & 0 & 0,025 & 0,047 \\
\hline 2 & 18,65 & 12,21 & 6,45 & 9,75 & 12,21 & 0,252 & $-0,0108$ & 1,09 & 0,062 & 0,0323 & 0,025 & 0,025 & 0,032 \\
\hline 3 & 12,21 & 8,06 & 4,14 & 12,21 & 14,71 & 0,2 & $-0,0143$ & 1,17 & 0,06 & 0,0457 & 0,025 & 0,025 & 0,045 \\
\hline 4 & 14,71 & 9,72 & 4,99 & 8,06 & 9,71 & 0,221 & $-0,0131$ & 1,13 & 0,062 & 0,0404 & 0,025 & 0,03 & 0,04 \\
\hline 5 & 9,71 & 5,78 & 3,94 & 9,71 & 12,70 & 0,195 & $-0,0152$ & 1,25 & 0,059 & 0,0618 & 0,03 & 0,03 & 0,061 \\
\hline 6 & 12,70 & 7,64 & 5,06 & 5,78 & 7,64 & 0,221 & $-0,0132$ & 1,16 & 0,062 & 0,0522 & 0,03 & 0,045 & 0,053 \\
\hline 7 & 7,64 & 4,87 & 2,77 & 7,64 & 9,54 & 0,163 & $-0,0140$ & 1,27 & 0,054 & 0,0626 & 0,045 & 0,05 & 0,062 \\
\hline 8 & 9,54 & 6,07 & 3,46 & 4,87 & 6,07 & 0,183 & $-0,0127$ & 1,20 & 0,057 & 0,0563 & 0,05 & 0,06 & 0,056 \\
\hline 9 & 6,07 & 3,86 & 2,21 & 6,07 & 7,53 & 0,145 & $-0,0141$ & 1,35 & 0,049 & 0,0641 & 0,06 & 0,02 & 0,063 \\
\hline 10 & 7,53 & 4,87 & 2,66 & 3,86 & 4,87 & 0,16 & $-0,0164$ & 1,32 & 0,053 & 0,0601 & 0,02 & 0 & 0,059 \\
\hline
\end{tabular}

Примітки: $h_{0}$ i $h_{1}$ - товщина розкату на вході і виході осередку; $\Delta h$ - абсолютне обтиснення; $V_{0}$ i $V_{1}-$ швидкість розкату при вході і виході з осередку; $V_{B}$ - швидкість поверхні валків; $F_{0}$ і $F_{1}-$ площа перерізу розкату до і після проходу; $R_{\kappa}$ - катаючий радіус валка; $B_{\kappa}$ - ширина калібру; $h_{s p}$ - глибина врізу калібру; $g-$ зазор; $\alpha_{\mathrm{y}}-$ кут контактування металу з валками; $\gamma$ - кут нейтрального перерізу; $\frac{\sigma_{0}}{2 K_{\mathrm{cp}}}$ и $\frac{\sigma_{1}}{2 K_{\mathrm{cp}}}-$ безрозмірні заднє і переднє питомі натяжіння; S - випередження. 


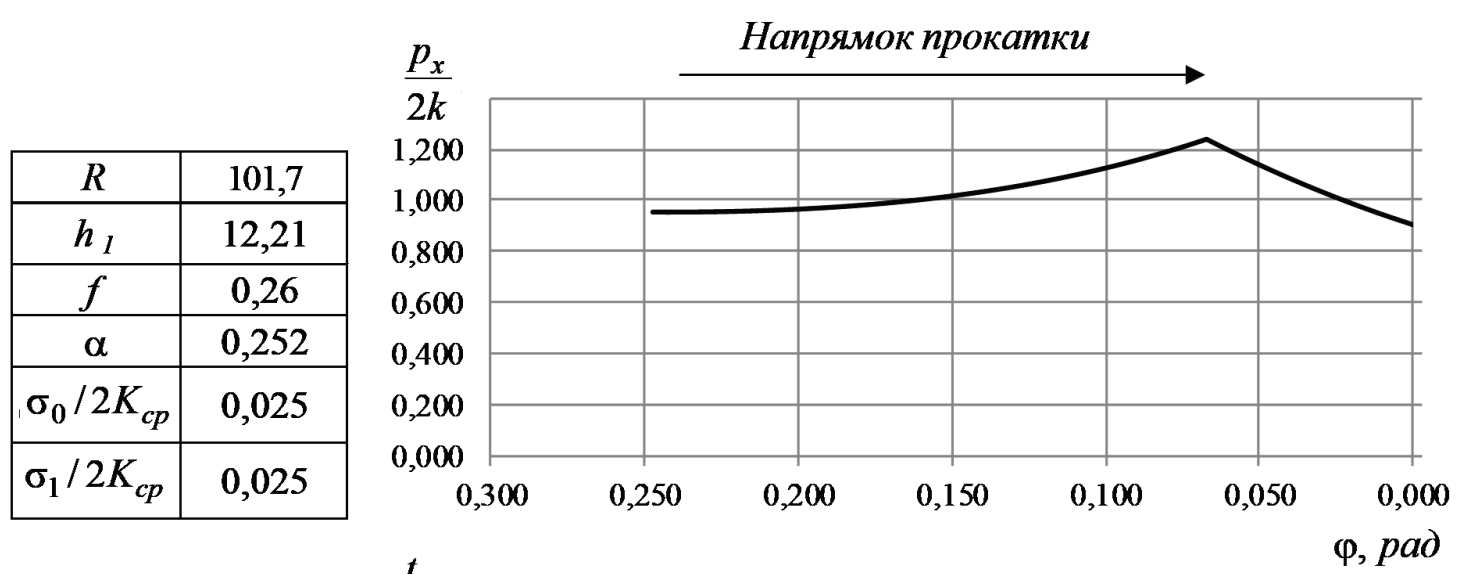

\begin{tabular}{|c|c|}
\hline$Q_{c p}^{*}$ & $-0,0108$ \\
\hline$p_{c p} / 2 K_{c p}$ & 1,08564 \\
\hline$M n p^{*}$ & 0,07183 \\
\hline$\gamma$ & 0,06231 \\
\hline
\end{tabular}
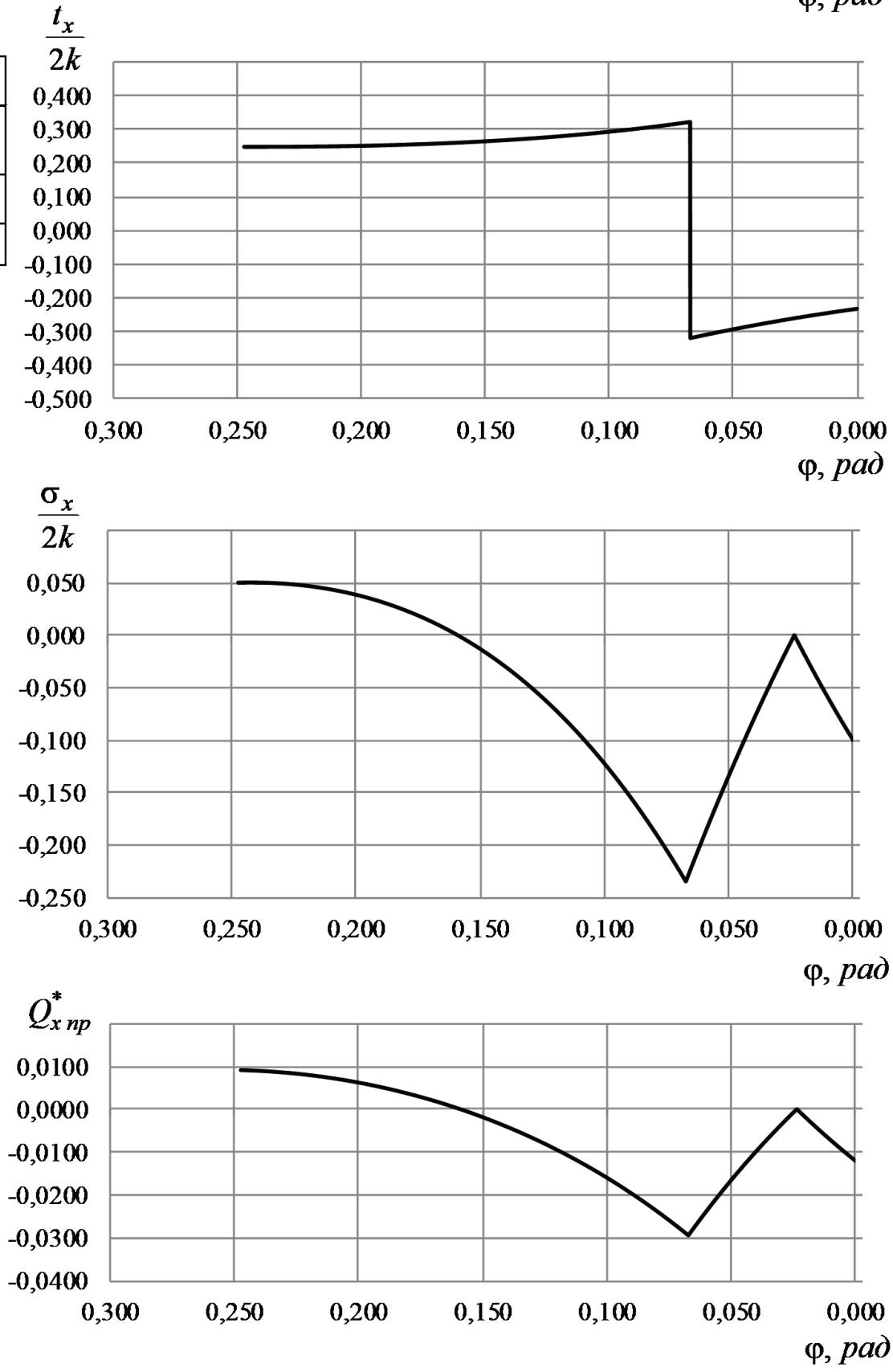

Рис. 1. Контактні та внутрішні напруження, поточні поздовжні сили при прокатуванні в другій кліті дротового блоку 
Аналогічні розрахункові таблиці отримали для всіх інших прийнятих значень коефіцієнтів тертя. За отриманими даними побудовані залежності основних параметрів процесу прокатування від коефіцієнту тертя, які показані на рисунках $2-4$.

Як видно з рисунку 2, з збільшенням коефіцієнту тертя значення середньої результуючої поздовжніх сил $Q_{c p . n p .}^{*}$ зростає за абсолютною величиною для всіх клітей блоку. Це свідчить про позитивний вплив зростання тертя на сталість процесу прокатування. При

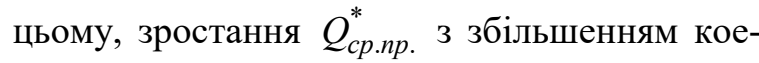
фіцієнту тертя має приблизно пропорційний характер, а розподіл по клітям блоку практично не змінюється. За отриманими значеннями показника $Q_{c p . n p .}^{*}$, найбільш сталим процес прокатування $є$ для першої кліті, найменш сталим - другої кліті 3 поступовим зростанням сталості до чистової кліті.

Питомі міжклітьові натяжіння, 3 зростанням коефіцієнту тертя, змінюються неоднозначно (рисунок 3). Для клітей № 1 та № 2 отримали зменшення міжклітьового натяжіння 3 зростанням коефіцієнту тертя для всіх значень, що прийняті в розрахунках. Для клітей № 3 та № 4 отримали протилежний характер зміни натяжіння від коефіцієнту тертя. Для наступних клітей знову - 3 збільшенням коефіцієнту тертя натяжіння зменшується. При цьому, для всіх рівнів коефіцієнту тертя отримали зростання натяжіння до кліті № 8 та різке зменшення в кліті № 9. Але, в цілому по блоку, з збільшенням коефіцієнту тертя величини міжклітьових натяжінь зменшуються. Так для кліті № 8 при коефіцієнті тертя 0,26 максимальне безрозмірне переднє натяжіння становить 0,06 . Збільшення коефіцієнту тертя до 0,32 призводить до зменшення переднього натяжіння в цій кліті до 0,0395 .

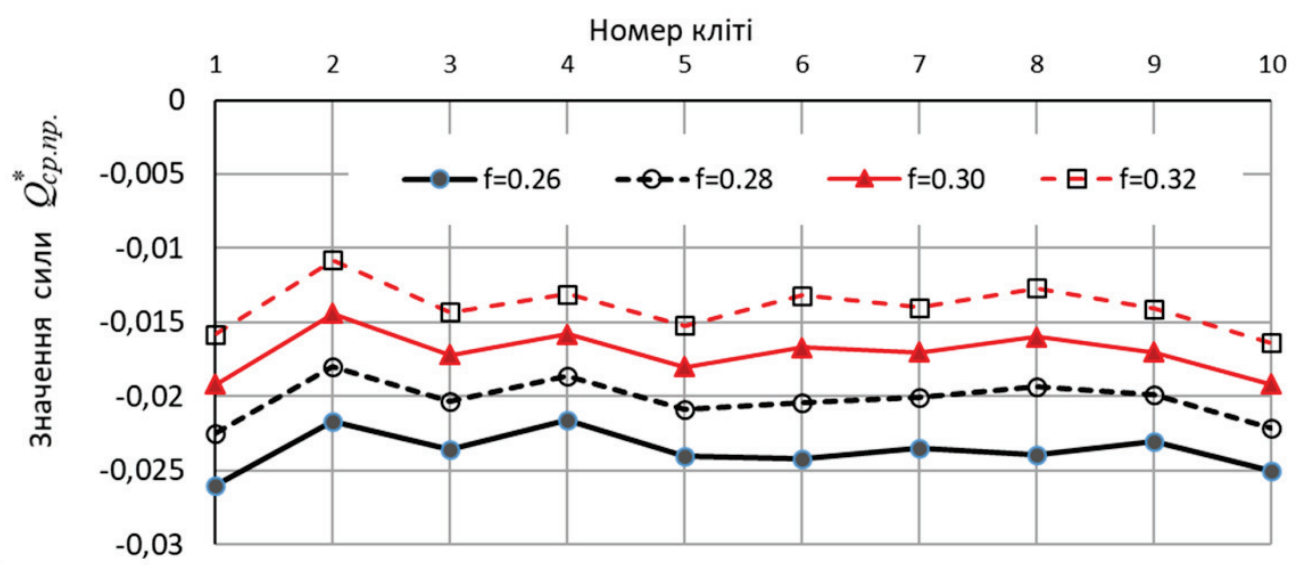

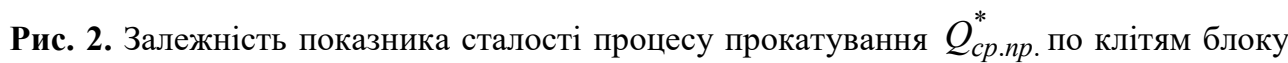
від коефіцієнту тертя

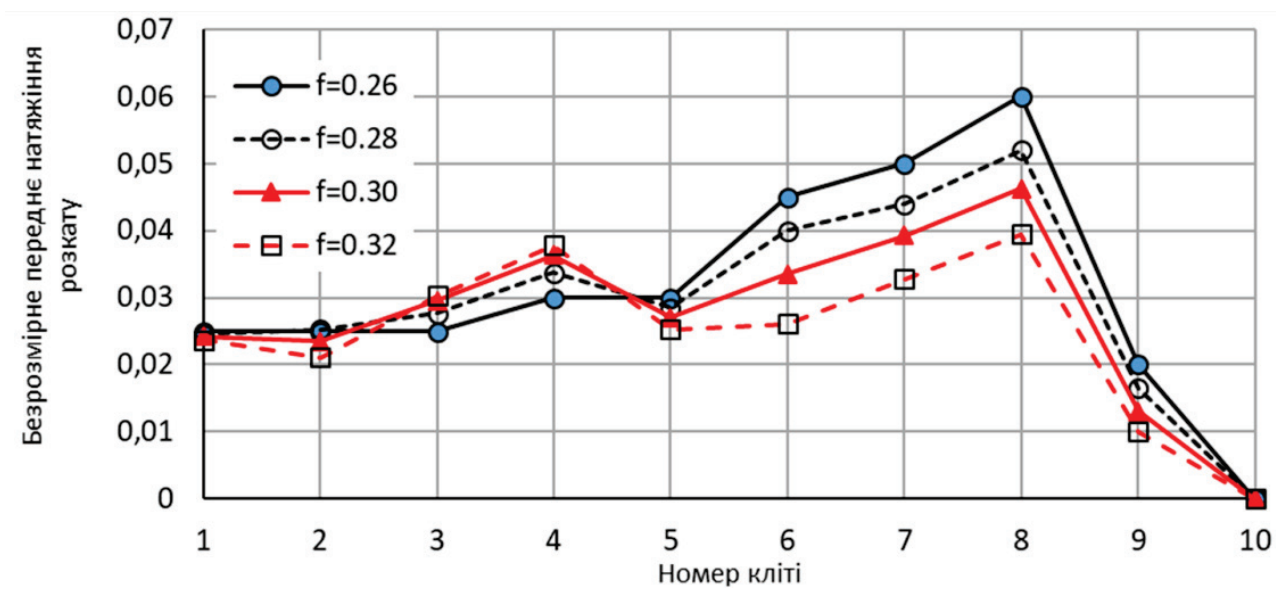

Pис. 3. Залежність міжклітьових питомих натяжінь $\sigma_{1} / 2 K_{c p}$ від коефіцієнту тертя 


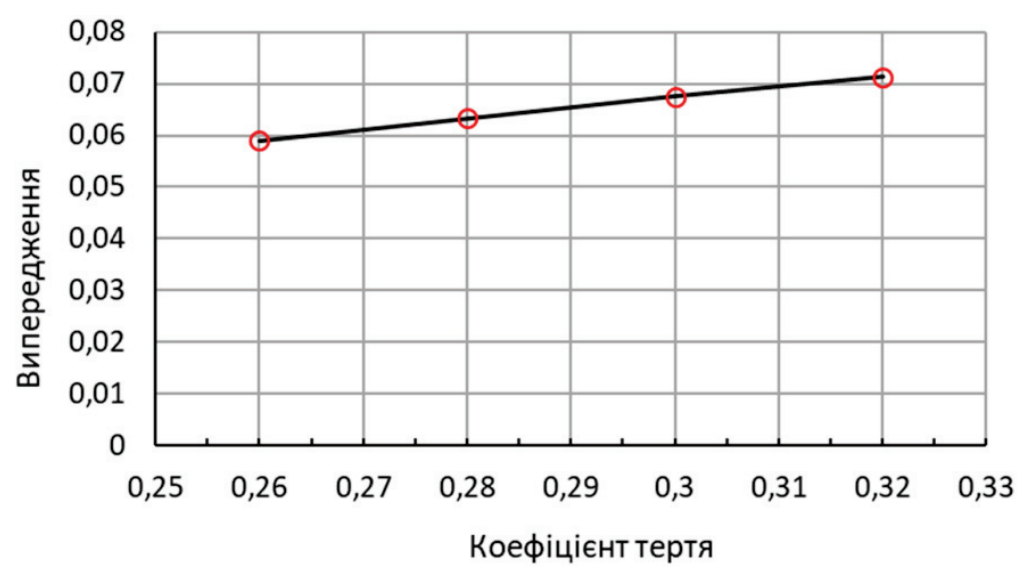

Рис. 4. Залежність випередження металу від коефіцієнту тертя для останньої кліті боку

Показана на рисунку 4 залежність розрахункового випередження в чистовій кліті № 10 від коефіцієнту тертя відповідає відомим положенням теорії прокатування. Слід зауважити, що таке збільшення випередження сприяє збільшенню продуктивності прокатного стану.

Для аналізу впливу режиму обтиснень на зміну параметрів прокатування виконали розра- хунки для випадку збільшеного обтиснення в першій кліті блоку.

Порівняння результатів розрахунків для звичайного обтиснення в першій кліті $\left(\Delta h_{1}=6,3 \mathrm{мм}\right)$ та збільшеного $\Delta\left(h_{1}=6,5 \mathrm{мм}\right)$ за однакового коефіцієнту тертя 0,3 , наведено в таблиці 2.

Таблиця 2. Вплив зміни обтиснення в першій кліті на параметри прокатування в дротовому блоці

\begin{tabular}{|c|c|c|c|c|c|c|c|c|c|c|c|}
\hline \multicolumn{2}{|c|}{ Параметр } & \multicolumn{10}{|c|}{ Значення параметрів для клітей блоку } \\
\hline № & познач. & 1 & 2 & 3 & 4 & 5 & 6 & 7 & 8 & 9 & 10 \\
\hline \multirow{2}{*}{1} & $\Delta h$ & 6,3 & 7,28 & 4,68 & 5,64 & 4,44 & 5,7 & 3,13 & 3,91 & 2,49 & 3,0 \\
\hline & $\Delta h^{\prime}$ & 6,5 & 7,39 & 3,94 & 4,37 & 3,04 & 3,14 & 1,87 & 1,87 & 1,91 & 2,05 \\
\hline \multirow{2}{*}{2} & $h_{1}$ & 11,0 & 13,78 & 9,10 & 10,96 & 6,52 & 8,63 & 5,50 & 6,85 & 4,36 & 5,50 \\
\hline & $h_{1}{ }^{\prime}$ & 10,8 & 13,74 & 9,80 & 10,94 & 7,90 & 8,67 & 6,80 & 6,83 & 4,92 & 5,51 \\
\hline \multirow{2}{*}{3} & $b_{1}$ & 21,05 & 13,78 & 16,60 & 10,96 & 14,33 & 8,63 & 10,76 & 6,85 & 8,50 & 5,50 \\
\hline & $b_{1}^{\prime}$ & 21,13 & 13,74 & 15,31 & 10,94 & 11,81 & 8,67 & 8,70 & 6,83 & 7,56 & 5,51 \\
\hline \multirow{2}{*}{4} & $V_{1}$ & 13,65 & 16,66 & 20,93 & 26,30 & 33,84 & 42,50 & 53,41 & 67,30 & 85,32 & 104,66 \\
\hline & $V_{1}^{\prime}$ & 13,67 & 16,52 & 20,79 & 26,08 & 33,43 & 41,54 & 52,71 & 66,81 & 83,9 & 102,9 \\
\hline \multirow[b]{2}{*}{5} & $S$ & 0,056 & 0,0407 & 0,0538 & 0,0488 & 0,0699 & 0,0619 & 0,0709 & 0,0647 & 0,0719 & 0,068 \\
\hline & $S^{\prime}$ & 0,057 & 0,032 & 0,047 & 0,040 & 0,057 & 0,038 & 0,057 & 0,057 & 0,054 & 0,050 \\
\hline \multirow[b]{2}{*}{6} & $\frac{\sigma_{1}}{2 K_{c p}}$ & 0,0242 & 0,0235 & 0,0295 & 0,0367 & 0,0270 & 0,0335 & 0,0393 & 0,0462 & 0,0130 & 0,0 \\
\hline & $\left(\frac{\sigma_{1}}{2 K_{c p}}\right)$ & 0,020 & $-0,025$ & $-0,050$ & $-0,01$ & $-0,065$ & $-0,15$ & $-0,05$ & 0,059 & 0,035 & 0,0 \\
\hline \multirow{2}{*}{7} & $Q_{c p . n p .}^{*}$ & $-0,022$ & $-0,018$ & $-0,020$ & $-0,018$ & $-0,021$ & $-0,020$ & $-0,020$ & $-0,019$ & $-0,019$ & $-0,022$ \\
\hline & $\left(Q_{c p . n p .}^{*}\right)^{\prime}$ & $-0,023$ & $-0,020$ & $-0,026$ & $-0,031$ & $-0,030$ & $-0,032$ & $-0,028$ & $-0,019$ & $-0,016$ & $-0,018$ \\
\hline
\end{tabular}

Примітки: В обох випадках прокатування коефіцієнт тертя приймали $f=0,3$. Константа прокатки (секундний об'єм) для існуючого режиму прокатування становила $2481 \cdot 10^{3} \mathrm{~mm}^{3} / \mathrm{c}$, а для випадку зі зміненим режимом обтиснень $-2449 \cdot 10^{3} \mathrm{~mm}^{3} / \mathrm{c}$. 
3 аналізу отриманих даних слідує, що, порівняно невелике, збільшення обтиснення призводить до збільшення розширення, зміни константи прокатування (умови постійності об'єму) та відповідних змін параметрів прокатування по всім клітям блоку. Зокрема, безрозмірне переднє натяжіння для клітей 3 № 2 до № 7, змінює знак, тобто замість натяжіння отримуємо підпір. Прокатування з підпором небажане, так як можлива втрата сталості процесу через накопичення металу в міжклітьових проміжках (петля).

Безрозмірна середня результуюча поздовжня сила, як показник сталості процесу прокатування, для перших семи клітей блоку зросла по абсолютній величині, для кліті № 8 - не змінилась, а для клітей № 9 та № $10-$ зменшилась. Отже, згідно отриманих даних, навіть незначні зміни режиму обтиснень можуть призводити до суттєвих змін параметрів прокатування в дротовому блоці.

\section{Висновки}

3 збільшенням коефіцієнту тертя поздовжня сталість процесу прокатування по всій лінії дротового стану збільшується 3 одночасним зменшенням питомого натяжіння розкату в міжклітьових проміжках. Така зміна параметрів сприяє підвищенню точності прокату та створює умови для збільшення продуктивності.

За відносно незначних змін обтиснення в першій кліті блоку спостерігаються суттєві зміни режиму натяжіння між клітями та неоднозначні зміни показника сталості процесу прокатування.

\section{Бібліографічний перелік}

1. Кугушин А. А., Попов Ю. А. Высокоскоростная прокатка катанки. М. : Металлургия, $1982.220 \mathrm{c}$.

2. Теоретические и технологические основы высокоскоростной прокатки катанки / А. Горбанев и др. Минск : Выс. шк., 2003. 287 с.

3. Иводитов А. Н., Горбанев А. А. Разработка и основы технологии производства высококачесвенной катанки. М. : Металлургия, 1989. $256 \mathrm{c}$.

4. Юнг Х., Кратчер И. Опыт эксплуатации редукционного стана для горячей прокатки катанки. Черные металльы. 1962. № 22. С. 52-62.

5. Dale J. R. Einadrige Schnell Drahtstraße Pacific Steel Ltd. Kalibrienrung. 1971. № 15. P. $55-62$.
6. Максименко О. П., Кузьмин Е. В. Саморегулирование процесса с учетом внутренних продольных сил при прокатке в проволочном блоке. Металлургическая и горнорудная промышиленность. 2017. № 6. С. 16-21.

7. Максименко О. П., Марченко К. К. Методика и результаты исследования износа калибров валков при прокатке катанки в проволочном блоке. Металлургическая и горнорудная промышленность. 2018. № 2. С. 20-24.

8. Грудев А. П. Захватывающая способность прокатных валков. М. : СП Интермет Инжиниринг, 1998. 288 с.

9. Максименко О. П., Лобойко Д. И., Измайлова М. К. Продольная устойчивость полосы в валках с анализом контактных условий. Сборник научных работ Днепродзержинского государственного технического университета (Технические науки). Днепродзержинск : Изд-во ДГТУ, 2016. $212 \mathrm{c.}$

10. Максименко О. П. Никулин А. А., Романюк Р. Я. Теоретический анализ захватывающей способности валков в установившемся режиме прокатки. Изв. вузов. Черная металлургия. 2009. №10. С. 32-34.

11. Максименко О. П., Романюк Р. Я. Исследования средней результирующей горизонтальных сил в очаге деформации. Изв. вузов. Черная металлургия. 2009. № 10. С. 22-24.

12. Грудев А. П. Теория прокатки: Учебник для вузов. М. : Металлургия, 1988. 248 с.

13. Целиков А. И. Теория расчета усилий в прокатных станах. М. : Металлургиздат, 1962. $414 \mathrm{c}$.

\section{References}

1. Kuhushyn, A. A., \& Popov, Yu. A. (1982). Vysokoskorostnaia prokatka katanky [High speed rolling wire rod]. Moskva: Metallurhyia

2. Horbanev, A. A., Zhuchkov, S. M., Fylyppov, V. V., Tymoshpolskyi, V. I., Steblov, A. B., Yunakov, A. M., \& Tyshchenko, V. A. (2003). Teoretycheskye $i$ technolohycheskye osnovy vysokoskorostnoi prokatky katanky [Theoretical and technological foundations of high-speed rolling wire rod]. Mynsk: Vysshaia shkola

3. Ivodytov, A. N. \& Horbanev, A. A. (1989). Razrabotka i osvoenye technolohyy proyzvodstva vysokokachestvennoi katanky [Development and mastering of high quality wire rod production technology]. Moskva: Metallurhyia

4. Yunh, H., \& Kratcher, I. (1962). Opyt ekspluatatsyy reduktsyonnoho stana dlia horiachei 
prokatky katanky [Operating experience of a reduction mill for hot rolling of wire rod]. Stahl und Eisen, (22), 52-62

5. Dale, J. R. (1971). Einadrige Schnell Drahtstraße Pacific Steel Ltd. Kalibrienrung, (15), $55-62$

6. Maksymenko, O. P., \& Kuzmyn, E. V. (2017). Samorehulyrovanye protsessa $s$ uchetom vnutrennykh prodolnykh syl pry prokatke $\mathrm{v}$ provolochnom bloke [Self-regulation of the process taking into account the internal longitudinal forces during rolling in a wire block]. Metallurhycheskaia $i$ hornorudnaia promyshlennost, (6), 16-21

7. Maksymeno, O. P., \& Marchenko, K. K. (2018). Metodyka y rezultaty issledovanyia iznosa kalybrov valkov pry prokatke katanky $v$ provolochnom bloke [Methods and results of the study of wear gauge rolls when rolling rod in a wire block]. Metallurhycheskaia $i$ hornorudnaia promyshlennost, (2), 20-24

8. Hrudev, A. P. (1998). Zakhvatyvaiushchaia sposobnost prokatnykh valkov [The bite ability of the rolls]. Moskva: SP Yntermet Enzhynyrynh

9. Maksymenko, O. P., Loboiko, D. Y., \&
Yzmailova, M. K. (2016). Prodolnaia ustoichyvost polosy $v$ valkakh $s$ analyzom kontaktnykh uslovyi [Longitudinal stability of the strip in the rolls with the analysis of contact conditions]. Sbornyk nauchnykh rabot Dneprodzerzhynskoho hosudarstvennoho tekhnycheskoho unyversyteta (Tekhnycheskye nauky). Dneprodzerzhynsk: DDTU

10. Maksymenko, O. P., Nikulin, O. V., \& Romaniuk, R. Ia. (2009). Teoretycheskyi analyz zakhvatyvaiushchei sposobnosty valkov $\mathrm{V}$ ustanovyvshemsia rezhyme prokatky [Theoretical analysis of the bite ability of rolls in steady state rolling.]. Yzv. vuzov. Chernaia metallurhyia, (10), 32-34

11. Maksymenko, O. P., \& Romaniuk, R. Ia. (2009). Yssledovanyia srednei rezultyruiushchei horyzontalnykh syl v ochahe deformatsyy [Studies of the average resulting horizontal forces in the deformation zone]. Yzv. vuzov. Chernaia metallurhyia, (10), 22-24

12. Hrudev, A. A. (1988). Teoryia prokatky [Rolling theory]. Moskva: Metallurhyia

13. Tselykov, A. Y. (1962). Teoryia rascheta usylyi v prokatnykh stanakh [Theory of calculation of efforts in rolling mills]. Moskva: Metallurhyia

Максименко Олег Павлович, професор, доктор технічних наук, завідувач кафедри обробки металів тиском, Дніпровський державний технічний університет (м. Кам'янське, Україна). ORCID ID: 0000-0003-0846-9869.E-mail: 0976776379max@gmail.com

Самохвал Володимир Михайлович, доцент, кандидат технічних наук, доцент кафедри обробки металів тиском, Дніпровський державний технічний університет (м. Кам'янське, Україна). ORCID ID: 0000-0003-0585-7225. E-mail: volsamokhval@gmail.com

Оробцев Андрій Юрійович, кандидат технічних наук, начальник технічного управління ПАТ «Дніпровський металургійний комбінат» (м. Кам’янське, Україна).

Нікулін Олександр Вікторович, доцент, кандидат технічних наук, доцент кафедри обробки металів тиском, Дніпровський державний технічний університет (м. Кам'янське, Україна). ORCID ID: 0000-0002-3509-7266. E-mail: av_nikulin@ukr.net

Марченко Костянтин Костянтинович, аспірант, кафедра обробки металів тиском, Дніпровський державний технічний університет (м. Кам’янське, Україна). E-mail: k.marchenok@gmail.com

\section{МОДЕЛЮВАННЯ ПРОЦЕСУ ПРОКАТУВАННЯ В КЛІТЯХ ДРОТОВОГО БЛОКУ}

Метою роботи є дослідження впливу умов тертя в осередку деформування і режиму обтиснень на поздовжню сталість процесу та міжклітьові натяжіння розкату при прокатуванні в дротовому блоці.

Методика проведення досліджень передбачала математичне моделювання процесу прокатування в клітях дротового блоку з визначенням середньої результуючої внутрішніх сил в металі, що пластично деформується, та інших параметрів процесу.

Результати. Встановлено, що з збільшенням коефіцієнту тертя поздовжня сталість процесу прокатування по всій лінії дротового блоку збільшується з одночасним зменшенням питомого натяжіння розкату в міжклітьових проміжках, а при незначних змінах обтиснення в першій кліті блоку спостері- 
гаються суттєві зміни режиму натяжіння між клітями та неоднозначні зміни показника сталості процесу прокатування.

Наукова новизна отриманих результатів полягає у розробці математичної моделі процесу прокатування, яка дозволяє визначати, окрім відомих параметрів, середню результуючу поздовжніх сил в якості критерію сталості процесу, та підтвердженні можливості застосування такої моделі для дротових блоків з жорстким кінематичним зв’язком між клітями.

Практична цінність результатів роботи зводиться до використання розробленої моделі, виявлених особливостей зміни параметрів по клітям блоку при розробці і удосконаленні технології прокатування катанки, а також у можливості використання моделі для коригування режимів обтиснень 3 метою забезпечення мінімальних міжклітьових натяжінь та сталості процесу по клітям блоку.

Ключові слова: сталість процесу прокатування, моделювання, коефіцієнт тертя, натяжіння, дротовий блок.

Oleh Maksimenko, Doctor of Technical Science, full professor, Head of the Department of Metal Pressure Processing, Dniprovsk State Technical University (Kamyanske, Ukraine). ORCID ID: 0000-0003-08469869. E-mail: 0976776379max@gmail.com

Volodymyr Samokhval, Candidate of Technical Sciences, Associate Professor of the Department of Metal Pressure Processing, Dniprovsk State Technical University (Kamyanske, Ukraine). ORCID ID: 00000003-0585-7225. E-mail: volsamokhval@gmail.com

Andrii Orobtsev, Candidate of Technical Sciences, Head of the Technical Management, PJSC "Dneprovsk Iron \& Steel Integrated Works" (Kamyanske, Ukraine)

Oleksandr Nikulin, Candidate of Technical Sciences, Associate Professor of Department of Metal Pressure Processing, Dniprovsk State Technical University (Kamyanske, Ukraine). ORCID ID: 0000-00023509-7266. E-mail: av_nikulin@ukr.net

Kostiantyn Marchenko, graduate student of the Department of Metal Pressure Processing, Dniprovsk State Technical University (Kamyanske, Ukraine). E-mail: k.marchenok@gmail.com

\section{MODELING OF THE ROLLING PROCESS IN THE WIRE ROD BLOCK MODULES}

The purpose of the investigation is to study the effect of friction conditions in the deformation zone and the regime reduction on the longitudinal stability of the process and the interstand tension of the workpiece when rolling in a wire block.

Methods. The investigation methodology involved mathematical modelling of the rolling process in the stands of the wire block with determination of the average resultant internal forces in the deformable metal and other process parameters.

Results. It is established that with increase of the coefficient of friction, the longitudinal stability of the rolling process on all the stands of the wire block increases with the simultaneous decrease of the specific tension of the workpiece in the interstand intervals, and with slight changes in the reduction in the first stand of the block.

The originality of these results is the development of a mathematical model of the rolling process, which allows to determine, in addition to the known parameters, the average resulting longitudinal forces as a criterion for the sustainability of the process, and to confirm the possibility of using such a model for wire blocks with rigid kinematic coupling between stands.

The practical implications of the results of the work lies in the possibility of using the developed model, the revealed features of changing the parameters on the stands of the block in the development and improvement of rolling technology, as well as the ability to use the model to adjust the regime reduction in order to ensure minimum interstand tensions and the stability of the process on the block.

Key words: rolling stability, modelling, coefficient of friction, tension, wire block. 
Максименко Олег Павлович, профессор, доктор технических наук, заведующий кафедры обработка металлов давлением, Днепровский государственный технический университет (г. Каменское, Украина). ORCID ID: 0000-0003-0846-9869. E-mail: 0976776379max@gmail.com

Самохвал Владимир Михайлович, доцент, кандидат технических наук, доцент кафедры обработка металлов давлением, Днепровский государственный технический университет (г. Каменское, Украина). ORCID ID: 0000-0003-0585-7225. E-mail: volsamokhval@gmail.com

Оробцев Андрей Юрьевич, кандидат технических наук, начальник технического управления ПАО «Днепровский металлургический комбинат» (г. Каменское, Украина).

Никулин Александр Викторович, доцент, кандидат технических наук, доцент кафедры обработка металлов давлением, Днепровский государственный технический университет (г. Каменское, Украина). ORCID ID: 0000-0002-3509-7266. E-mail: av_nikulin@ukr.net

Марченко Константин Константинович, аспирант кафедры обработка металлов давлением, Днепровский государственный технический университет (г. Каменское, Украина). E-mail: k.marchenok@gmail.com

\section{МОДЕЛИРОВАНИЕ ПРОЦЕССА ПРОКАТКИ В КЛЕТЯХ ПРОВОЛОЧНОГО БЛОКА}

Целью работы является исследование влияния условий трения в очаге деформации и режима обжатий на продольную устойчивость процесса и межклетевые натяжения раската при прокатке в проволочном блоке.

Методика проведения исследований состояла в математическом моделировании процесса прокатки в клетях проволочного блока с определением средней результирующей внутренних сил в пластически деформируемом металле и прочих параметров процесса.

Результаты. Установлено, что с увеличением коэффициента трения продольная устойчивость процесса прокатки по всей линии проволочного блока увеличивается с одновременным уменьшением удельного натяжения раската в межклетевых промежутках, а при незначительных изменениях обжатия в первой клети блока наблюдается существенные изменения режима натяжений между клетями и неоднозначные изменения показателя устойчивости процесса прокатки.

Научная новизна полученных результатов состоит в разработке математической модели процесса прокатки, которая позволяет определять, кроме известных параметров, среднюю результирующую продольных сил в качестве критерия устойчивости процесса, и подтверждении возможности применения такой модели для проволочных блоков с жесткой кинематической связью между клетями.

Практическая ценность результатов работы сводится к использованию разработанной модели процесса, выявлению особенностей изменения параметров по клетям блока при разработке и усовершенствовании технологии прокатки катанки, а также в возможности использования модели для корректировки режимов обжатий с целью обеспечения минимальных межклетевых натяжений и устойчивости процесса по клетям блока.

Ключевые слова: устойчивость процесса прокатки, моделирование, коэффициент трения, натяжение, проволочный блок. 